FUNDAMENTAL BRITISH VALUES IN EDUCATION

Radicalisation, National Identity and Britishness 


\title{
FUNDAMENTAL BRITISH VALUES IN EDUCATION \\ Radicalisation, National Identity and Britishness
}

\author{
By \\ LYNN REVELL \\ School of Teacher Education and Development, \\ Canterbury Christ Church University, \\ Canterbury, UK \\ HAZEL BRYAN \\ School of Education, University of Gloucestershire, \\ Cheltenham, UK
}

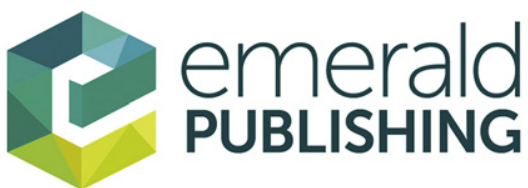

United Kingdom - North America - Japan India - Malaysia - China 
Emerald Publishing Limited

Howard House, Wagon Lane, Bingley BD16 1WA, UK

First edition 2018

Copyright (C) 2018 Emerald Publishing Limited

Reprints and permissions service

Contact: permissions@emeraldinsight.com

No part of this book may be reproduced, stored in a retrieval system, transmitted in any form or by any means electronic, mechanical, photocopying, recording or otherwise without either the prior written permission of the publisher or a licence permitting restricted copying issued in the UK by The Copyright Licensing Agency and in the USA by The Copyright Clearance Center. Any opinions expressed in the chapters are those of the authors. Whilst Emerald makes every effort to ensure the quality and accuracy of its content, Emerald makes no representation implied or otherwise, as to the chapters' suitability and application and disclaims any warranties, express or implied, to their use.

British Library Cataloguing in Publication Data

A catalogue record for this book is available from the British Library

ISBN: 978-1-78714-508-5 (Print)

ISBN: 978-1-78714-507-8 (Online)

ISBN: 978-1-78714-953-3 (Epub)

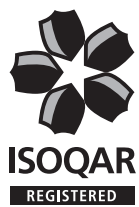

Certificate Number 1985

ISO 14001
ISOQAR certified Management System, awarded to Emerald for adherence to Environmental standard ISO 14001:2004.

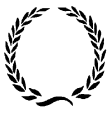

INVESTOR IN PEOPLE 
To Bertie Townhill and John Revell 


\section{CONTENTS}

Introduction

\section{PART ONE}

1. Radicalisation and Fundamental British Values 7

2. Otherness, National Identity and the Language of Values

\section{PART TWO}

3. Professionalism, Pedagogy and

Counter-Terrorism: The Role of the Teacher in New Times

4. The Case for Liquid Professionalism

5. Conclusion

References

Index 